\title{
Other minds and God: Russell and Stout on James and Schiller
}

Tim Button

button@cantab.net

University of Cambridge

This paper is due to be published in a collection edited by Maria Baghramian and Sarin Marchetti. This is a pre-print and may be subject to minor alterations. The authoritative version should be sought in the published collection.

In 1907-8, Russell and Stout presented an objection against James and Schiller, to which both James and Schiller replied. In this paper, I shall revisit their transatlantic exchange. Doing so will yield a better understanding of Schiller's relationship to a worryingly solipsistic brand of phenomenalism. It will also allow us to appreciate a crucial difference between Schiller and James; a difference which James explicitly downplayed.

As I understand Russell and Stout's objection, it concerns James and Schiller's account of content. Russell and Stout complain that, by James and Schiller's own lights, the content of the claim 'other minds exist' concerns only my private experience. Since I clearly wish to go beyond my private experience, when I speak of other minds, James and Schiller's pragmatism should be rejected. That is the nerve of the Russell-Stout objection (see $\$ 1$ ).

To illustrate the Russell-Stout objection, I shall introduce a particular philosophical character whom I call the locked-in-phenomenalist (see $\$ 2$ ). This character wants to construct the entire world—other minds and all—from her own phenomenology. Unsurprisingly, her ambitions are thwarted. She is able to perform constructions which, in her terms, license her in saying 'other minds exist'. However, by her own lights, the content of that claim concerns nothing more than her private experiences. As such, the locked-in-phenomenalist is clearly vulnerable to Russell-Stout.

My locked-in-phenomenalist is something of a caricature. Sadly, her position is worryingly close to Schiller's. In particular, Schiller's discussion of how we 'make' reality is extremely similar to the locked-in-phenomenalist's description of our 'construction' of the world. Consequently, Schiller is just as vulnerable to Russell-Stout as the locked-in-phenomenalist (see $\$ 3)$.

The story is rather different when it comes to James. Despite James's insistence that he and Schiller are in agreement, I show that James is able to avoid Russell-Stout (see $\$ 4$ ). According to James, the content of the claim 'other minds exist' concerns entities which transcend my (possible) experience in certain key regards. This is all very welcome. However, it has consequences for other aspects of James's pragmatism. In particular, it shows that James was wrong to claim in Pragmatism (1907) that his pragmatism would deliver quick solutions to the question of God's existence ( 


\section{The Russell-Stout objection}

The focus of this paper is an objection raised by Russell and Stout against James and Schiller. I shall start with Russell's formulation of the objection. He writes:

According to the pragmatists, to say 'it is true that other people exist' means 'it is useful to believe that other people exist.' $(1908,400)$

Russell continues:

But if I am troubled by solipsism, the discovery that a belief in the existence of others is 'true' in the pragmatist's sense is not enough to allay my sense of loneliness: the perception that I should profit by rejecting solipsism is not alone sufficient to make me reject it. For what I desire is not that the belief in solipsism should be false in the pragmatic sense but that other people should in fact exist. $(1908,403)$

In raising this criticism, Russell drew explicitly from Stout, who had offered essentially the same criticism of Schiller:

My sympathy with my neighbour's headache presupposes that he is actually feeling it. But according to Mr. Schiller's theory, my belief in other minds might be as true as truth can be, even though there were no emotions, feelings, desires, purposes, etc., experienced by any one except myself. All that, in his view, is required to constitute truth, is that I should postulate experiences other than mine, and that this postulate should enable me to control my own experiences. The postulate would still be true even though I were merely dreaming of the existence of other minds, provided that it gave me a guiding clue for actively determining the development of my dream. $(1907,585)$

I shall now outline how this objection is supposed to work, in the first instance.

Russell and Stout suggest that James and Schiller endorse a general theory of truth, to the effect that 'it is true that $p$ ' has the same meaning as 'it is useful to believe that $p$ '. Whatever the details of 'usefulness' amount to, they hold that James and Schiller are committed to all biconditionals of this shape:

$$
\text { it is useful to believe that } p \text { iff it is true that } p
$$

However, Russell and Stout then suggest that there could be cases where it is useful to believe that $p$, even though not- $p$. Their example is the case when 'other minds exist' passes all pragmatic tests - so that it is useful to believe that other minds exist-even though there are no other minds. Though Russell and Stout do not make the final step completely explicit, I take it that the point is as follows. We can surely assume that: 
Combining this with the supposed pragmatist theory of truth, James and Schiller should therefore always accept:

if it is useful to believe that $p$, then $p$

and that is just what we seem to lack, when $p$ is other minds exist.

As just formulated, Russell and Stout's criticism focusses on a particular theory of truth which they attribute to James and Schiller. However, the kernel of their argument can be restated without mentioning truth, and there are two good reasons for doing so. First: it not clear whether James or Schiller actually endorses a theory of truth of the form that Russell and Stout ascribe to them. ${ }^{1}$ Second: avoiding mention of truth will make clear that the real focus of the objection does not concern truth, but content. ${ }^{2}$

Let me repeat the earlier quotation from Russell:

According to the pragmatists, to say 'it is true that other people exist' means 'it is useful to believe that other people exist.' $(1908,400)$

Suppose we simply replace 'it is true that other people exist' with 'other people exist'. Then Russell's complaint will be that 'other people exist' means something only about my experiences, namely, 'it is useful to believe that other people exist'. One might immediately complain that neither James nor Schiller subscribes to any such theory of meaning. I shall, of course, say much, much more about this below. Setting this aside for now though, Russell's complaint should continue as follows. What James and Schiller claim to mean by 'other people exist' is neither what I mean, nor what I care about. For — paraphrasing Russell — what I desire is not that it is useful to believe that other people exist, but that other people should in fact exist.

We can similarly remove mention of truth from Stout's objection. Following Stout, I want to be able to sympathise with someone for their headache. But—continuing with Stout - when James or Schiller claims 'other minds, complete with headaches, exist', the content of the claim concerns only my experiences. And that falls short of what I wanted.

We can summarise the above as follows:

The Russell-Stout Objection. By James and Schiller's own lights, the content of 'other minds exist' only concerns my experiences, and that is inadequate.

\footnotetext{
${ }^{1}$ The particular concern is whether James or Schiller endorse the conditional: if it is useful to believe that $p$, then it is true that $p$. James's fullest treatment of truth provides us only with a series of necessary conditions on truth (1904, 474-5, points 1-7; 1909, 100-1, points 1-6). Likewise, Schiller affirms that 'all truths work', but he is not prepared to affirm 'all that works is true' (1911, 163-5; 1912b; 1913).

${ }^{2}$ Cf. McTaggart's (1908, 106-7) criticism of James.
} 
This objection is the focus of my paper. I should, though, briefly comment on the chosen example. We can easily imagine a Russell-Stout-esque complaint which focuses, not on other minds, but on chairs. It might run as follows:

By James and Schiller's own lights, the content of 'the chair is made from wood' only concerns my experiences, and that is inadequate. After all, as Dewey put the point against phenomenalism, I want to be able talk about 'the chair which was bought, that is placed in a room and that is used to sit in, etc.' $(1929,17)$.

That would be a good objection. Nonetheless, I shall continue to focus on other minds. My reason for this is essentially dialectical. It is one thing to insist, hard-headedly, that 'the chair is made from wood' expresses no content beyond my own experiences. It is quite another thing to insist that anything I say concerning 'other minds' fails to go beyond my own experiences.

\section{The locked-in-phenomenalist}

Before considering what James and Schiller (should have) said in response to Russell-Stout, it will help me to introduce a character who is definitely vulnerable to Russell-Stout. I call this character the locked-in-phenomenalist. Crudely, the locked-in-phenomenalist wants to construct the entire world from her raw phenomenology. I have two reasons for introducing her: first, because she presents us with a clear victim of Russell-Stout; second, because understanding her plight will help us to understand Schiller's.

In setting out the character of the locked-in-phenomenalist, I shall draw extensively on Carnap's Aufbau (1928). To be clear, I am not arguing here that Carnap is a locked-inphenomenalist. If you like, you can regard me just as offering the locked-in-phenomenalist reading' of Carnap's Aufbau. For everything said in this paper, this might be a dreadful misreading of Carnap himself. ${ }^{3}$

So. According to Carnap — on this reading - 'the subjective starting point of all knowledge lies in experiential-contents and their interrelations' (1928, $\$ 2$ ). Carnap then uses logicomathematical methods to manipulate these experiences. In so doing, he constructs 'an intersubjective, objective world', from those initial experiences basis $(1928, \$ 2)$. The details of Carnap's logico-mathematical methods need not detain us. All that matters, for our purposes, are the experiences with which we start.

Carnap describes 'the subjective starting point of all knowledge' as the autopsychological basis. This comprises subjective, first-personal, mental experiences. Importantly, however, they are to be considered 'as they are given'. Indeed, following Husserl's phenomenological tradition,

\footnotetext{
${ }^{3}$ Although I do think that Carnap's Aufbau exemplifies locked-in-phenomenalism. In the terms of the present paper, I think that the most interesting feature of the Aufbau is Carnap's ingenious attempts to show how he can avoid Russell-Stout, despite being a locked-in-phenomenalist. But I cannot pursue that topic here.
} 
we are to bracket them. At the outset, we cannot ask what is causing them; nor what is going on 'behind them'; nor what they designate; nor what they signify; nor whether they are veridical or falsidical. We cannot ask any of this, because none of this information is present in the experiences 'as they are given'. It is only later, once we have constructed the entire external world on the basis of these experiences, that we can even think of the experiences as having one cause rather than another, or as being (in)accurate. But, at the outset, we are to restrict ourselves to pure phenomenology. Carnap calls this phenomenological starting point the stream of experience, or the Given $(1928, \$ 64)$. To summarise: the aim is to construct the entire external world from purely phenomenological beginnings; from the Given.

Since the Russell-Stout objection is my focus, my particular concern is with Carnap's construction of a specific part of the external world, namely, the other minds. According to Carnap, physical objects are constructed at a certain stage in the process of constructing the world from the Given. One such physical object is to be 'my body'. ${ }^{4}$ Now, suppose that $M$ is some physical object which is distinct from but physically similar to my body. On this basis, I can ascribe mental states to $M$. In particular, I can construct $M$ 's given, by analogy with the Given. And then, just as I constructed the world from the Given, so I can construct what one might call 'M's world' from 'M's given' (1928, \$145). But crucially, during the entire construction of this other mind,

The autopsychological basis is not here abandoned; all of ' $M$ 's objects' are still objects of the one constitution system and thus go back ultimately to the basic object of that system, so to a relation that holds between the elementary experiences (my experiences!). One can, however, speak in a certain sense of 'the constitutional system of $M$ ' [what we called 'M's world'], but nothing more is to be understood by this than a certain branch of 'the' (or 'my') constitution system [what we called 'the world'], that branches off at a high level. $(1928, \$ 145)$

The crucial point is that the psychology of some other person, $M$, incorporates nothing new. Rather 'the entire experience sequence of the other person consists in nothing other than $a$ rearrangement of my own experiences and their components' (1928, \$140).

This concludes the locked-in-phenomenalist reading of Carnap's Aufbau. To repeat: my aim here is not to defend this as a good reading of Carnap himself; I am just using Carnap's text as a means to introduce the character of the locked-in-phenomenalist. And this character simply endorses everything that, for better or worse, we have just read into Carnap. In particular, the locked-in-phenomenalist cheerfully says that 'the entire experience sequence of the other person consists in nothing other than a rearrangement of my own experiences and their components.'

\footnotetext{
4 'Physical objects' are constructed as projections from my visual field onto mathematical surrogates for spacetime points. 'My body' is then singled out by a 'definite description' which comprises claims like: '[m]y body is always near my eye'; 'the visible surface [of my body] is an open surface, since some parts of its surface, e.g. eye and back, are invisible'; etc. (Carnap 1928, \$129). How mental states then 'get attached' to my body is a good question, but one I shall not discuss here.
} 
As such, the locked-in-phenomenalist is clearly vulnerable to Russell-Stout. Certainly the locked-in-phenomenalist will be happy to assert 'other minds exist'. After all, her experiences lead her to perform certain constructions, on the basis of which she says 'there are many other people, together with their minds'. But, as she has admitted herself, any claim which she makes about 'the external world' - including the claim 'other minds exist' — goes 'back ultimately to ... the elementary experiences (my experiences!)'. Thus she contends that the content of 'other minds exist' only concerns her experiences. And that is surely inadequate, as RussellStout contends.

In this section, I have introduced the locked-in-phenomenalist, and shown why she is clearly vulnerable to Russell-Stout. Her difficulties help us to understand the nature of RussellStout, and we should keep in mind her fate as we begin to consider how Russell-Stout applies to James and Schiller. At the risk of ruining the surprise: in $\$ 3$, I shall show that Schiller is much too close to being a locked-in-phenomenalist, and so succumbs to Russell-Stout. Then in $\$ 4$, I shall show that James's pragmatism is importantly different from Schiller's, and so avoids Russell-Stout.

\section{Schiller's proximity to locked-in-phenomenalism}

To begin my discussion of Schiller, I shall highlight several ways in which Schiller is extremely close to locked-in-phenomenalism.

\section{'Making' reality}

Schiller tells us that 'the whole world in which we live is experience and built up out of nothing else than experience' $(1902,51)$. Moreover, he ultimately answers the question, 'whose experience is it?', by saying, ' $m y$ experience' $(1902,52) .{ }^{5}$ As for the locked-in-phenomenalist, then, Schiller's aim is to 'make' the world from a purely first-person starting point.

Schiller calls this starting point 'primary reality', and he explains it as follows:

In the wider sense everything is 'fact,' qua experienced, including imaginings, illusions, errors, hallucinations. 'Fact' in this strict sense is anterior to the distinction of 'appearance' and 'reality' and covers both. To distinguish it we may call it 'primary reality.' Its existence is undeniable, and in a sense most important. For it is the starting-point, and final touchstone, of all our theories about reality,

\footnotetext{
${ }^{5}$ In fairness to Schiller, he hesitates slightly. His full answer is “our experience," or, if that imply too much agreement among philosophers, and I may not take a common world for granted, more precisely, " $m y$ experience."' My point here is that Schiller is happy enough to slip from methodological 'populipsism' to methodological solipsism. I conjecture that Schiller is happy to do this, since he thinks that, even as a methodological solipsist, he will succeed in establishing a world populated with other minds (cf. my diagnosis of James in \$4). Unfortunately, as we shall see, he is wrong about this. Note that all of this helps to contextualise Schiller's remark to James, in a letter of 19 December 1909, that 'You seem to think that my procedure commits me to a methodological solipsism' (Skrupskelis and Berkeley 2003, 391).
} 
which have for their aim its transformation. It may, certainly, in a sense, be called 'independent' of us, if that comforts any one. For it is certainly not 'made' by us, but 'found.' But, as it stands, we find it most unsatisfactory and set to work to remake it and unmake it. And it cannot possibly be taken as 'real fact' or 'true reality.' For, as immediately experienced, it is a meaningless chaos, merely the raw material of a cosmos, the stuff out of which real fact is made. (1907a, 187)

Schiller's primary reality is, then, strikingly close to the phenomenological starting point of our locked-in-phenomenalist. One point of agreement is particularly worth highlighting. At the 'outset'-i.e. when the locked-in-phenomenalist considers the Given, or when Schiller considers primary reality — the experiences are bracketed. In particular: at the 'outset', it makes no sense to ask whether experiences are veridical or falsidical, merely apparent or real. I can only ask these questions once I have introduced these distinctions. And I can only introduce these distinctions by first making a world. But I make that world, and introduce these distinctions, on and only on the basis of what is most expedient given the bracketed starting point. This is why Schiller could say, in a letter to James of 19 January 1907, that 'the distinction between "true" \& "false" perception (hallucination \&c) is itself a pragmatic one" (Skrupskelis and Berkeley 2003, 304).

With all this in mind, let us turn to Schiller's comments on how 'secondary reality' - the 'external world' - is made. Here is Schiller:

the objects of true perception ... are, in fact, creatures of our thought, constructed out of the crude material of our passing experiences (Erlebnisse), in order to regulate our lives and to guide our expectations. They are, in short, essentially pragmatic in their nature and function, and though they may be said to 'transcend' the fleeting experiences to which they serve as an ideal support, this transcendence is merely the expression of our postulate that there shall be such relatively stable pegs on which to hang the streaming strands of the phenomena that eddy around us. $(1909 c, 96)$

Schiller's use of the word 'postulate' is slightly idiosyncratic, and I shall revisit this below. But, bracketing this for now, the entire quotation could have come straight from the mouth of our locked-in-phenomenalist.

The similarities between Schiller and the locked-in-phenomenalist are quite clear. However, I should comment on two differences.

First, Schiller's notion of 'making' reality is genuinely temporal. The locked-inphenomenalist's 'constructions' are atemporal: to speak of 'construction', as if it were a process, is to adopt a convenient methodological fiction for describing some abstract logic/mathematics. By contrast, according to Schiller, my 'making' of the world takes place in time, and I constantly 'remake' it. This is why Schiller writes to James on 25 October 1907, explaining that primary reality is not really 'a psychical starting point in adult life'; for in adult life our reality 'is always more or less "made"' (Skrupskelis and Berkeley 2003, 469). 
Second, as Yolton (1950) emphasizes, Schiller's notion of 'making' reality involves some voluntary and personal contribution from the subject who does the 'making'. Consequently, Yolton claims that Schiller 'did not wish to advocate the kind of idealism which asserts that we posit the "other" out of our own self $(1950,52)$. Instead, Schiller ends up advocating 'some sort of subjective idealism in which the external world is not conceived wholly in terms of sense data but in which the "something other than sense data" is made to depend, for its specific nature, upon the human' contribution $(1950,53){ }^{6}$

We can summarize these two differences briefly. According to Schiller, I can unmake and remake what $\mathrm{I}$ have made, and my making involves my distinctive contribution. But these differences do not much matter when it comes to Russell-Stout. Crucially, if crudely: you have no say over how I make you. This, indeed, is why Schiller is prepared to say things like this:

Every sort of distinct perceptual object..., alike whether it be a 'thing' or a 'person,' seems to be manifestly man-made, i.e., relative to the human interests which singled it out, and preserve for it its status as a 'reality' which it is expedient to take into account. $(1910 \mathrm{a}, 226)^{7}$

Just as for the locked-in-phenomenalist, so for Schiller: talk of another 'person' ultimately goes back to $m e$. This is why Schiller is vulnerable to Russell-Stout.

For his part, Schiller made two points in reply to Russell-Stout. Unfortunately, as I shall show in the remainder of this section, both are entirely ineffectual. Schiller treats Stout as simply having accused him of being a solipsist, ${ }^{8}$ and replies by insisting that he is not (1909b, 170). As such, Schiller fails to engage with the nerve of Russell-Stout, which concerns Schiller's views on the content of the claim 'other minds exist'.

\section{Schiller's 'pragmatic rebuttal' of solipsism}

In letters to James of 10 July 1905 and 10 January 1908 (Skrupskelis and Berkeley 2003, 72, 516), Schiller complains that it is unfair to single out humanism (or pragmatism) as particularly unable to refute the charge of solipsism. He develops these points further in print, arguing that his humanism is uniquely well placed to demonstrate its opposition to solipsism. In particular, whilst humanists can freely explore the hypothesis of solipsism, they are almost

\footnotetext{
${ }^{6}$ Yolton suggests that Schiller is led towards this 'subjective idealism' due to 'a very fundamental confusion', namely, 'the failure to distinguish between ontological and epistemological reality at every level of his discussion' $(1950,56)$. He then suggests that we should remove these confusions, on Schiller's behalf, and insist that 'the making of reality for Schiller is epistemological and not ontological' $(1950,57)$.

This reading provides Schiller with a clear response to Russell-Stout. However, it comes at the cost of declawing Schiller. Yolton's declawed Schiller is not the man who claimed that 'pragmatism as an epistemological method' falls short of his Humanism (1905, 239); who raged against the very idea of 'transcendent correspondences' (1907b, 600); who denied 'that in ultimate analysis there can persist a discrepancy between the true and the useful' (1912a, 103); or who wrote any of the passages quoted in this section.

${ }^{7}$ cf. also Schiller's letter to James of 10 July 1905 (Skrupskelis and Berkeley 2003, 72).

${ }^{8}$ Schiller responds to Stout's formulation rather than Russell's. (Schiller's 1908 reply to Russell's 1908 does not touch upon Russell-Stout.) James and Schiller both thought highly of Stout's (1907) critical notice of Schiller 1907a, but were fairly unimpressed by Stout's version of Russell-Stout; see the letter from James to Schiller of 16 October 1907, and Schiller's reply on 25 October 1907 (Skrupskelis and Berkeley 2003, 461-2 and 468-9).
} 
certain to reject it in the end, since solipsism is unlikely to sit well with their experiences (1907a, 471-3; 1909a, 128; 1909b, 170). This supplies a 'pragmatic rebuttal' of solipsism. Schiller then adds that anyone who rejects solipsism will ultimately have to employ the same 'pragmatic rebuttal' themselves. The only difference is that Schiller will be honest and upfront about its nature.

This, then, is Schiller's first response to Russell-Stout. Unfortunately, it fails to make contact with the objection. Russell and Stout have not claimed that Schiller is unwilling to say 'other minds exist'. The nerve of their objection is simply that, if Schiller were right about 'making' reality, then 'other minds exist' would not mean that other minds exist. Nothing in Schiller's 'pragmatic rebuttal' of solipsism has even spoken to this point.

To highlight this, note that a locked-in-phenomenalist can offer exactly the same 'pragmatic rebuttal' of solipsism. The locked-in-phenomenalist, like the humanist, can freely explore the hypothesis of solipsism. However, the locked-in-phenomenalist will ultimately reject it, since (what she calls) 'solipsism' will not sit well with her experiences. After all, her experiences will lead her to constructions which license her in saying 'other minds exist'. None of this, though, does anything to dispel the point that, by the locked-in-phenomenalist's own lights, the content of 'other minds exist' concerns only her experience.

\section{A distinction between two kinds of postulates}

Schiller's second response to Stout concerns his idiosyncratic use of the term 'postulate', as raised earlier. From 1902 onwards, Schiller talks in terms of postulates which may or may not be confirmed by experience. The postulate relevant to the Russell-Stout objection is 'other minds exist', and Stout phrases his version of Russell-Stout in terms of that postulate (see the quote in $\$ 1$ ). Schiller replies that Stout has failed to see that there are two different ways to lay down a postulate:

(1) It may be held that certain experiences behave as if there were other minds behind them. If so, this postulate need not lead to a belief in the existence of other minds. But if (2) other minds are postulated as existing, then the confirmation of this postulate by its working seems necessarily to prove that other minds really and truly exist. A mere appeal to postulation thus leaves either of these ways open; but only the first could be correctly described as compatible with Solipsism (1909b, 170n.1)

Schiller insists that he embraces method-(2), and as such is not a solipsist. Now, this reply is less obviously orthogonal to Russell-Stout than Schiller's 'pragmatic rebuttal' of solipsism, since postulating as existing rather than as if might lead to some difference in content. However, neither method of postulation really helps Schiller to deal with Russell-Stout.

To show this, I shall start by considering method-(1). The chief difficulty here is in understanding what Schiller means by the expression 'as if. When we think this through, we shall see that method-(1) is not compatible with solipsism, even according to Schiller. 
Suppose that someone is looking at a straight stick which is partly immersed in water. To them, it is as if the stick is bent, even though the stick it is not actually bent. However, it is only as if the stick is bent, for so long as they merely look at the stick. If they move the stick out of the water, or if they touch the stick with their hands, then it will no longer be as if the stick is bent. This is the sort of thing which allows Schiller to make a distinction between its being as if the stick is bent, and the stick's actually being bent.

Suppose, however, that someone accepts that it is as if $p$, for absolutely all intents and purposes, but refrains from thinking that it is actually the case that $p$, and merely treats it as a useful 'fiction' to claim that $p$. Then, Schiller says, they have made a philosophical mistake: they are in the grip of the dastardly "copy" theory of truth'. After all, '[b]ut for their continuing to think it the business of truth to copy (or represent or reflect) reality ..., there would be no reason to dub our practical procedures "fiction" (1912a, 99). ' So, if it is as if $p$ for absolutely all intents and purposes, then-according to Schiller-it is the case that $p$.

With this appreciated, let us return to solipsism. The solipsist might well say that it is as if other minds exist. But, in saying this, she is not suggesting that the apparent minds are like the apparently bent stick. If we move the stick out of the water, or we touch it, we can confirm that it is really straight. But the solipsist is quite explicitly not suggesting that some test will reveal that there are no other minds after all. The hypothesis is not that a more thorough inspection will lead us to realise that some apparently-mind-possessing thing is merely a crude automaton. On the contrary, the solipsist agrees that it is as if there are other minds, for absolutely all intents and purposes. But then, given what we saw above, Schiller must regard the solipsist as a victim of the "copy" theory of truth'.

Consequently, by Schiller's own lights, method-(1) of postulating 'other minds' is incompatible with solipsism. We must instead focus on method-(2). This is, in any case, how Schiller claims to postulate 'other minds'.

Concerning method-(2), Schiller claims that 'the confirmation of this postulate by its working seems necessarily to prove that other minds really and truly exist'. But this is just much too blasé, not least because anyone who worries about solipsism will question the necessity of the connection between confirmation and existence. Moreover, and more specifically, Schiller is only prepared to accept the necessity of that confirmation, because he takes it that the content of the claim 'other minds exist' only concerns what works (i.e. something about my experiences). This is reinforced by the observation we just made, that Schiller can see no gap between its being as if there are other minds for absolutely all intents and purposes, and there actually being other minds. But, so the worry goes, anyone who can see no gap here must be a victim of Russell-Stout. For the whole point of saying 'other minds exist' is to go beyond what works for me, i.e. beyond $m y$ experiences.

To bring all of this home, note that the locked-in-phenomenalist can say exactly the same things as Schiller about postulates. Like Schiller, the locked-in-phenomenalist can distinguish

\footnotetext{
${ }^{9}$ See also Schiller $(1911,164-5 n$.) and Schiller's suggestion to James, in a letter of 25 October 1907, that Stout's formulation of Russell-Stout 'arises out of a momentary relapse into the intellectualist theory of truth' (Skrupskelis and Berkeley 2003, 469).
} 
between its being as if a stick is bent, and its actually being bent. After all, certain experiences lead her to speak of 'the stick'; certain experiences may lead her to say 'the stick looks bent'; but her best overall account of 'the external world' ultimately leads her to say that 'the stick is straight but looks bent under certain circumstances'. What the locked-in-phenomenalist cannot do, though, is make sense of a general attitude of fictionalism, for that would certainly require that her (entirely successful) constructions be answerable to a world beyond her subjective experiences. Finally - and for just this reason-she too insists that the postulate 'other minds exist' is necessarily confirmed by the experiences she in fact has, since, by her own lights, the content of that postulate just concerns her experiences. None of this, though, rebuts Russell-Stout; it merely repeats that the locked-in-phenomenalist is a victim of RussellStout.

The upshot is clear. Schiller's notion of 'making' reality is much too close to locked-inphenomenalism, and nothing Schiller says in reply to Russell-Stout establishes any important distance. Indeed, his replies display an inability to understand what the Russell-Stout objection really was. Schiller, in short, succumbs to Russell-Stout.

\section{James as a naïve realist}

I shall now turn my attention to James. I shall begin by outlining his expressions of naive realism. These afford James an excellent reply to Russell-Stout. Unfortunately, James somewhat obscures this reply, by explicitly claiming to share Schiller's problematic views. However, I shall argue that this was a mistake on his part, and that the (sincerely) naive realist James avoids Russell-Stout.

\section{James's expressions of naïve realism}

In several places in The Meaning of Truth (1909), James embraces naïve realism. For example, he explains that his account of truth is fully object-involving. He writes: 'Truth is essentially a relation between two things, an idea, on the one hand, and a reality outside of the idea, on the other' $(1909,163)$. Moreover, 'the existence of the object, whenever the idea asserts it "truly," is the only reason, in innumerable cases, why the idea does work successfully, if it work at all' $(1909, \mathrm{xv}-\mathrm{xvi})$. He adds that, when he had advanced his views on truth in earlier publications, 'My mind was so filled with the notion of objective reference that I never dreamed that my hearers would let go of it' $(1909,233)$.

James says similar things concerning reality and its objects. For example: 'This notion of a reality independent of us, taken from ordinary social experience, lies at the base of the pragmatist definition of truth' $(1909,217-8)$. And 'as a pragmatist I have so carefully posited "reality" ab initio, and ..., throughout my whole discussion, I remain an epistemological realist' $(1909,195)$. That is, James postulates 'a standing reality independent of the idea that knows 
it' (1909, 158). Elsewhere, James explicitly assumes 'the point of view of naï realism or common sense' $(1909,50$ n. $){ }^{10}$

\section{Schiller's criticisms of James}

Predictably, Schiller is a bit bemused by all of this. His bemusement comes through rather beautifully in his reaction to James's discussion of Julius Cæsar $(1909,221-5$, published a year earlier). James is considering the question of how we can think about Cæsar, even though he is long since 'dead and turned to clay'. In the course of his discussion, James says that the truth of our utterance 'Cæsar exists' depends upon the existence of Cæsar (223-4). This should be utterly banal, but Schiller writes to James on 10 April 1908 with concern:

I cannot see how the objective fact of e.g. Cæasar's death can ever transcend the evidence on the strength of which we preferred to believe in the historical tradition. Anything that affects the tradition affects pro tanto the objective reality of Cæsar. (Skrupskelis and Berkeley 2004, 6) ${ }^{11}$

Astonishingly, Schiller here shows that he is incapable even of registering that Cæsar's life and Cæsar's experience might transcend our present evidence.

Schiller's bemusement makes its way into print. ${ }^{12}$ In his critical notice of The Meaning of Truth (James 1909), Schiller writes that James lays 'what seems disproportionate stress on the question whether a pragmatist can believe in "real objects"' (1910b: 260). Schiller regards the question as hopelessly confused, and laments that James 'even seems to countenance the confused rationalistic putting of the question' $(1910 \mathrm{~b}, 262)$. For Schiller, the only worthwhile question, concerning the existence of an object, is 'simply one of the testing of a claim to reality' (1910b: 261). He is similarly critical of James's admission that truth involves 'a relation to a real object postulated to be there', asking 'what is the use of postulating a real object, apart from any means of testing whether it really is there?' (1910b, 262). Schiller, as usual, cannot even register that objects might transcend tests of which $I$ am the sole arbiter.

Schiller's rejection of naïve realism is exactly what we should predict of a victim of RussellStout. Conversely, James's willingness to embrace naïve realism allows him to give a simple reply Russell-Stout: As a naïve realist, I hold that the content of 'other minds exist' is no more nor

\footnotetext{
${ }^{10}$ More fully, James (1909, 50n.) claims that ch.II of his 1909 is written 'from the point of view of naif realism or common sense, and avoids raising the idealistic controversy'. As James notes (1909, 43n.1), this chapter is an extract from an earlier paper. Interestingly, in that earlier paper, James explicitly declared himself on the idealistic side $(1895,106)$.

${ }^{11}$ In his defence, Schiller notes that 'these are only first impressions' of James's essay on Cæsar. However, this is just one example of Schiller's private complaints about James's naïve realism. On 29 July 1904, Schiller had simply suggested 'you take things more realistically than I am wont to do, though I dare say the difference is more a matter of wording' (Skrupskelis and Berkeley 2002, 441). By October 1907, Schiller was outlining to James the 'plain humanist answer' which would feature in his critical notice of James 1909 (see below). And by 10 January 1908, Schiller was complaining 'I don't quite see why you sh $\mathrm{d}$ be so anxious to vindicate for us the right to use a realistic terminology', following up the point on 1 March 1908 (Skrupskelis and Berkeley 2003, 468, 516, 547 respectively).

12 Though, interestingly, he now describes the chapter on Julius Cæsar as 'particularly lucid and effective in clearing up misconceptions' (1910b, 259).
} 
less than that other minds exist, where other minds are objects independent from me and from my experiences.

\section{James's proximity to Schiller}

Ultimately, this is precisely what James should say against Russell-Stout. Unfortunately, though, the point is a little exegetically complicated, for James explicitly claims that he and Schiller are in agreement.

Both in private and in print, James insists that 'Schiller's doctrine and mine are identical, only our expositions follow different directions' $(1909,242)$. The difference is that James helps himself, at the outset, to terms which he believes Schiller will ultimately vindicate $(1909,244)$. According to James, Schiller is starting with the (auto)psychological and then successfully 'making' the entire world; James, instead, is anticipating the success of Schiller's project, and so is happy simply to start with this 'ready-made' world. Or, as he put the point in a letter to Schiller of 16 June 1908:

You start with the psychological subject claiming a statement of his to be 'true', \& verifying it by working towards conclusions which lead him to say 'these are the something, or the proximate marks of agreement with the something, which my statement meant.' I start with the something (calling it 'reality') \& ask what makes the statement 'true' of it, replying by instancing your verifying workings, as constituting the agreement in concreto. (Skrupskelis and Berkeley 2004, 30) ${ }^{13}$

James goes on to explain to Schiller the dialectical advantage of his way of approaching things:

because I start by postulating the reality which you only end by verifying, [our critics] are willing to say that I talk sense (at least some of them are!) but that you mean something different. (Skrupskelis and Berkeley 2004, 30)

In fact, James mentions this dialectical advantage repeatedly. ${ }^{14}$ Before penning his (critical) critical notice of The Meaning of Truth, Schiller briefly outlined its proposed contents to James, in a postcard of 26 October 1909, and asked 'Do you give your assent to this treatment?' (Skrupskelis and Berkeley 2004, 355). James replied on 6 November:

Of course I entirely assent to the treatment you propose. Your form of attacking the problem is doubtless logically more shipshape than mine, but I think that mine works perhaps more easily on the philosophic rabble. (Skrupskelis and Berkeley 2004, 361)

All of this, however, leads to a worrying thought: James's apparent commitment to naïve realism is a mere dialectical expedient. It is not, on this line of thought, that James has adopted an importantly different philosophical stance from Schiller; it is just that he wants to avoid getting

\footnotetext{
${ }^{13}$ See also James (1909, xviii-xix), his letters to Schiller of 20 March 1908, 16 June 1908, 5 January 1910 and 4 May 1910 (Skrupskelis and Berkeley 2003, 552; 2004, 409 and 493) and Schiller (1910b, 260).

${ }^{14}$ Indeed, in all the letters mentioned in the previous footnote.
} 
bogged down in the objections that have been raised against Schiller. However, so this thought runs, James believes that Schiller can ultimately answer those objections, and so 'make' the 'independent objects' that James wants to invoke. But this threatens to cast James's apparent naïve realism in a very different light. For if James's 'independent objects' are in fact to be 'made', Schiller-style, then James will fall right back into Russell-Stout.

We face a choice. We must either read James as a victim of Russell-Stout alongside Schiller, or prise James's naïve realism apart from Schiller's humanism.

I recommend the latter. Separating James from Schiller requires only that we attribute to James a mistaken (but sincere and charitable) belief concerning the prospects of his friend's philosophical project. ${ }^{15}$ And attributing this mistake to James allows him to avoid the (otherwise devastating) Russell-Stout objection. Moreover, as I shall now argue, a sincere commitment to naïve realism makes the best sense of James's most detailed discussions of other minds, in the final years of his life. ${ }^{16}$

\section{James's reply to Russell}

Where Schiller replied to Stout's formulation of Russell-Stout, James replied to Russell's. Here is the most direct part of his reply:

When I call a belief true, and define its truth to mean its workings, I certainly do not mean that the belief is a belief about the workings. It is a belief about the object, and I who talk about the workings am a different subject, with a different universe of discourse, from that of the believer of whose concrete thinking I profess to give an account.

The social proposition 'other men exist' and the pragmatist proposition 'it is expedient to believe that other men exist' come from different universes of discourse.... The first expresses the object of a belief, the second tells of one condition of the belief's power to maintain itself. $(1909,279-80)$

In this passage, James is very much alive to the Russell-Stout objection (and certainly much more alive to it than Schiller). After all, James is explicitly concerned with the content of the claim 'other minds exist'. Indeed, James himself drops the mention of truth from Russell's objection (as advocated in $\$ 1$ ).

\footnotetext{
${ }^{15}$ We might also speculate as to whether James misunderstands Schiller's project slightly. The discussion of 'verifying', in the letter of 16 June 1908, hints that James might take Schiller to be making only an epistemological point, and not a metaphysical one (cf. footnote 6). In this regard, it is worth commenting that James writes to Schiller on 19 April 1907, saying 'The Essays on Freedom \& the making of Reality [in Schiller 1907a] seem to be written with my own heart's blood-it's startling that two people should be found to think so exactly alike' (Skrupskelis and Berkeley 2003, 345). This might make it seem as if James unequivocally endorses Schiller's notion of 'making' reality. However, I would caution against that reading. The two essays which James mentions contain surprisingly little to indicate Schiller's proximity to locked-in-phenomenalism: read in isolation, they admit a more epistemological reading. Moreover, in the same letter James tells us that he has still 'only read about a quarter of [Schiller's book] even now'.

${ }^{16}$ Note that the reading should only be applied to the last few years of James's life (see footnote 10, above).
} 
That said, the reply is not entirely successful. If I say 'it is useful to believe that other minds exist', one can reasonably ask 'useful for whom?' If I clarify my position by saying 'it is useful for Sigi to believe that other minds exist', then I have clearly said something different than if I had simply said 'other minds exist'. After all, to paraphrase James: I, who talk about the workings of Sigi's belief, am a different subject than Sigi, with a different universe of discourse from that of Sigi. But suppose, instead, that I answer the question 'useful for whom?' by replying 'it is useful for me to believe that other minds exist'. Then it is no longer immediately clear that this has a different content than my claim 'other minds exist'. At the very least, I cannot try to show that it does by deploying the same line of reasoning as I did regarding Sigi, for it would be completely absurd to argue: I, who talk about the workings of my beliefs, am a different subject than me, with a different universe of discourse from me.

As such, James's invocation of 'different universes of discourse' does not immediately yield a convincing response to Russell-Stout. Nonetheless, in discussing the question of content, James clearly shows that he wanted to address Russell-Stout directly. And fortunately, although James does not present them in this way, other passages in The Meaning of Truth show us precisely what James should have said in reply to Russell-Stout.

\section{James on headaches}

At several points in The Meaning of Truth, James aims to explain someone can think about some object. He presents three memorable examples: thinking about the tigers in India; thinking about Memorial Hall; and finally, as mentioned above, thinking about Julius Cæsar (1909, respectively 43-50, 104-115, 221-5). In each of these cases, James's primary task is to explain that thinking about is an ambulatory relation, rather than a saltatory one. What he means by this is the following. When someone thinks about an object, their thought does not have to leap over some 'epistemological chasm' (i.e. thinking about is not saltatory) between the thinker and the thought-of object. Rather, there is a continuous chain of actual or potential experiences connecting the thinker with the thought-of object (i.e. thinking about is ambulatory). Finally, James insists that this chain can be explicated entirely in pragmatic terms.

James's contrast between ambulatory and saltatory relations tacitly makes contact with Russell-Stout, when James explicitly discusses an objection due to Pratt. Like Stout, Pratt is considering the case of thinking about someone else's headache, and writes:

If there be a succession of intermediaries between my thought and your headache-or between my thought and Nebuchadnezzar's headache-neither you nor I nor Nebuchadnezzar ever experiences the succession. My experience breaks off where yours begin. (Pratt 1909, 157-8)

The point of Pratt's criticism is this: precisely because someone else's headache is their headache rather than my own, there must be some 'saltatory' element when I think about it. And, in reply to Pratt, James concedes exactly this: 
I am still at one remove, and the headache 'transcends' me, even tho it be in nowise transcendent of human experience generally. But the 'gulf here is that which the pragmatist epistemology itself fixes in the very first words it uses, by saying there must be an object and an idea. The idea however does n't immediately leap the gulf, it only works from next to next so as to bridge it, fully or approximately. $(1909,178-9)$

This 'leap' over a 'gulf' is precisely what the locked-in-phenomenalist, and Schiller, quite simply cannot make sense of. So it is here that James finally and crisply separates himself from their company. And, just to reinforce the point, James closes the discussion as follows:

But to ask the pragmatist thereupon whether, when it thus fails to coalesce bodily with the object, [the idea of the other person's headache] is really true or has real trueness, - in other words whether the headache he supposes, and supposes the thinker he supposes, to believe in, be a real headache or not,-is to step from his hypothetical universe of discourse into the altogether different world of natural fact. $(1909,179)$

In this passage, James acknowledges that the question of whether there really is another mind-complete with a headache that is not James's - transcends 'his hypothetical universe of discourse'; that is, it transcends his 'vision of his hypothetical universe' (as James explains a few lines earlier). But James does not take this transcendence as a reason to dismiss the question, as the locked-in-phenomenalist or Schiller would have done. Rather, James labels it as a question of natural fact. So: James thinks that there can be natural facts, including headaches of other people, which involve stepping outside any one person's (even possible) 'hypothetical universe'. Otherwise put: James regards the question of whether 'other minds exist' as ultimately a matter of natural fact, and not a mere matter of my experiences. That is just to confirm James's status as a naïve realist about other minds, and so to say that James, ultimately, avoids Russell-Stout.

\section{James on God's existence}

I have argued that James and Schiller should be read as parting company in response to Russell-Stout. I want to close this paper, though, by considering how this parting of ways affects James's reflections on theism.

\section{God's existence in James's Pragmatism}

In his Pragmatism (1907), James attempts to illustrate the efficacy and benefits of the pragmatic method by applying it to the question of God's existence. His discussion climaxes in the announcement:

'God's in his heaven; all's right with the world!'-That's the real heart of your theology, and for that you need no rationalistic definitions. (1907, 121-2) 
This is clearly a claim about the content of 'God exists'. Moreover, James later summarises that discussion as follows:

Reducing, by the pragmatic test, the meaning of each of these concepts ['God,' 'freedom,' and 'design'] to its positive experienceable operation, I showed them all to mean the same thing, viz., the presence of 'promise' in the world. 'God or no God?' means 'promise or no promise?' $(1909, \mathrm{x})$

Again, this is a claim about the content of 'God exists'.

\section{Russell-Stout, as applied to 'God exists’}

The obvious complaint — which was raised by many of James's contemporaries-is that James's treatment of the phrase 'God exists' prevents it from meaning that God exists. And one way to put flesh on this objection is as follows.

Many theologies regard God as a person. Even if She is not the kind of person who has headaches, She is presumably the kind of person who has thoughts and feelings (thoughts concerning mercy; feelings of unconditional love; that sort of thing). Just as we consider another's headaches in sympathy, we may want to consider these thoughts and feelings in worship. But if James were right that the content of 'God exists' is merely that the cosmos holds promise, then when we think 'God exists', we fail to reach all the way out to God Herself and to Her thoughts (assuming She exists). The content of the claim inadequately terminates in the warm fuzzy glow it gives us.

This, of course, is a reapplication of Russell-Stout, to the case of 'God exists' rather than 'other minds exist'. And the comparison between the two cases becomes particularly interesting, when we consider exactly how James applied 'the pragmatic test' in Pragmatism.

A high-point of that discussion is James's attempt to demonstrate that 'Matter and God' in fact 'mean exactly the same thing', since ' $[t]$ he actually experienced world is supposed to be the same in its details on either' the hypothesis of theism or the hypothesis of materialism (1907, 99 and 98). So: suppose that we apply this very same 'pragmatic test', not to the case of materialism versus theism, but to hypotheses concerning other persons. On the one hand, we have the pluralistic hypothesis that there are other people with headaches and toothaches and so forth; and on the other hand, we have the solipsistic hypothesis that only I ever really experience anything. The worry is that, just as in the case of theism versus materialism, " $[t]$ he actually experienced world is supposed to be the same in its details on either hypothesis.' So, if we apply 'the pragmatic test' to the case of pluralism versus solipsism, in the same way as we applied that test to theism versus materialism, we will reach the conclusion that pluralism and solipsism 'mean exactly the same thing'. And that would turn James back into a victim of Russell-Stout.

Briefly stated, then, James seems to have one standard when it comes to 'human minds' and a different standard for 'divine minds'. Only such a double-standard could allow him to escape from Russell-Stout, as directed against other (human) minds, whilst drawing the semanticcum-metaphysical conclusion that theism and materialism are the same. 


\section{Imagined reply: embracing a double-standard}

James's writings provide some scope for the development of this double-standard. Immediately after meeting with Russell on 24 May 1908, James writes to him, explaining:

In a nutshell my opinion is this: that instead of there being one universal relation sui generis called 'truth' between any reality and an idea, there are a host of particular relations varying according to special circumstances and constituted by the manner of 'working' or 'leading' of the idea through the surrounding experiences of which both the reality and the idea are part. (Skrupskelis and Berkeley 2004, 18)

As Skrupskelis and Berkeley $(2004, \mathrm{xl})$ note, 'this formula leaves open at least the possibility that the truth relation in which the object is authoritative... is one kind of truth'. It similarly leaves open the possibility of a double-standard concerning content. One might maintain that discourse 'about other people' works in a different way than discourse 'about God', for they serve different purposes. The purpose of the former incorporates our desire to sympathise with another's headaches, whereas the purpose of the latter (perhaps) is to allow us to affirm (in certain special ways) that 'all's right with the world', or that the world has 'promise'. If so, then the content of discourse concerning 'other people' will make other people authoritative over their own existence (and headaches), whereas the content of discourse concerning 'God' grants 'Her' no similar authority.

However, as a purely descriptive matter, it is not very plausible to take the question 'God or no God?' as simply 'promise or no promise?' Those who seriously ask the question often take themselves to be considering the existence of a divine person. Now, one potential theological barrier to describing God as a 'person' is that it abases God, bringing Her too close to 'mere humans'. But to reduce the claim 'God is a person' to a claim, not about persons at all but about the world's promise, seems to constitute an entirely different order of sacrilege.

\section{Treating God as a person}

In fact, James does not pursue a double-standard concerning social and theistic discourse. In a letter of 16 October 1907 (Skrupskelis and Berkeley 2003, 462), James confided to Schiller about his 'bad conscience' concerning the claim that theism and materialism 'mean exactly the same thing'. Moreover, as I shall explain, his reasons for regret are deeply connected with the issue of God's personhood.

James asks us to consider:

an 'automatic sweetheart,' meaning a soulless body which should be absolutely indistinguishable from a spiritually animated maiden.... Would any one regard her as a full equivalent? Certainly not, and why? Because, framed as we are, our egoism craves above all things inward sympathy and recognition, love and admiration. The outward treatment is valued mainly as an expression, as a manifestation of the accompanying consciousness believed in. Pragmatically, 
then, belief in the automatic sweetheart would not work, and in point of fact no one treats it as a serious hypothesis. $(1909,189$ n.)

As I read this passage, James is not just making the narrow point that no one would believe 'my sweetheart is automatic' rather than 'my sweetheart has a mind'. (That narrow point would just amount to Schiller's attempted 'pragmatic rebuttal' of solipsism, which fails to dispel Russell-Stout.) This passage should rather be read in connection with the idea that another's headache is a natural fact. It is only because I recognise that my sweetheart has a mind, that 'the outward treatment' has the value it does. James continues this point, in his letter of 16 October 1907, by pointing out:

We wish to be sure of her interest in us, and that her responsive caresses are meant and felt. (Skrupskelis and Berkeley 2003, 462)

This passage has a significance for James which it cannot have for Schiller. For all of the italicised elements - and they are James's own italics - involve us in natural fact, separated from my experience by a 'gulf that my thought must ultimately leap. This is yet another way to see that James refuses to be a victim of Russell-Stout.

James, though, introduces the example of the automatic sweetheart so that he can explain why he wants to retract some of his remarks, in Pragmatism, concerning 'God exists'. James now maintains that his stance on the hypotheses of theism versus materialism should be 'exactly similar' to his stance on the hypotheses of a minded versus an automatic sweetheart:

Even if matter could do every outward thing that God does, the idea of it would not work as satisfactorily, because the chief call for a God on modern men's part is for a being who will inwardly recognize them and judge them sympathetically. Matter disappoints this craving of our ego, so God remains for most men the truer hypothesis, and indeed remains so for definite pragmatic reasons. $(1909,189$ n.)

As with the sweetheart, so with God. The important point here is not the narrow one, that many people want to believe in God. The point is that the value of the theistic hypothesis requires that the content of the claim 'God exists' relates us to a genuine person who is both empathetic and sympathetic. In this regard, 'other minds exist' and 'God exists' are to be treated on a par. There must be no double-standard, concerning 'human' and 'divine minds'.

Consequently, though, James should not just have recanted the claim that theism and materialism mean the same. He should also have recanted the claim that 'God or no God?' means 'promise or no promise?' His pragmatism neither provides us with quick answers to theological questions, nor provides us with easy reformulations of those questions in apparently non-theological terms. 


\section{Other minds, humans or divine}

When James attempted to explain 'the essence of humanism', he characterized it in terms of 'our experience' $(1909,124)$. Given the topic of this paper, the obvious question to ask is: who is James's 'we'? James answers: 'I myself read humanism theistically and pluralistically'. That is: his 'we' encompasses both a divine mind and many human minds.

Concerning the divine mind, James writes:

If there be a God, he is no absolute all-experiencer, but simply the experiencer of widest actual conscious span. $(1909,125)$

Here we find James explicitly conceding that, if his God exists, then She must be treated as just one (rather special) person among many. But She is not the 'absolute all-experiencer'. James's God does not experience my headache-She is not the self-absorbing Absolute-but only sympathises with me for having it.

Concerning other human minds, James writes:

Ethically the pluralistic form of [humanism] takes for me a stronger hold on reality than any other philosophy I know of-it being essentially a social philosophy, a philosophy of 'co,' in which conjunctions do the work. $(1909,125)$

For James, then, neither the content of 'other minds exist', nor the content of 'God exists', is limited to any one person's experience; not even God's.

Of course, one can ask why James treats humanism theistically and pluralistically. But the answer is in the text: it seems to James to provide him with the best way to make sense of the world of which he is a part. Otherwise put, James's reasons for theism and pluralism-his reasons, indeed, for naïve realism about other minds-are pragmatic, in a very broad sense.

In presenting his 'pragmatic rebuttal' of solipsism, Schiller attempts to make a similar point, at least concerning the existence of other minds. But it is no victory for any specific doctrine of pragmatism — and certainly not for Schiller's own brand of humanism - that our reasons for making certain claims are based upon our desire to make sense of our experiences (in the broadest sense of 'experiences'). The central point, which James could acknowledge, but Schiller could not, is this. In order for these claims to do the work I want them to-to satisfy my desire to understand the world of which I am a part- the content of those claims must reach beyond my experiences and desires, to the world itself. ${ }^{17}$

\footnotetext{
${ }^{17}$ I wrote this paper during a period of research leave which was funded by a Philip Leverhulme Prize (awarded by the Leverhulme Trust, PLP-2014-140). After I wrote this paper, I realised its oblique but deep debt to a conversation I once had with Brian King, Tom Stern, and James Williams. Thanks also to two anonymous referees, to Cheryl Misak and to Robert Trueman, and most of all to Alexander Klein, for great conversations about James and for encouraging me to think about James's letter to Russell of 24 May 1908.
} 


\section{References}

Carnap, Rudolf. 1928. Der logische Aufbau der Welt. Translated by Rolf A. George. 1967, Routledge \& Kegan Paul. I have departed slightly from George's translation.

Dewey, John. 1929. Experience and Nature. Second edition. London: George Allen \& Unwin. James, William. 1895. "The Knowing of Things Together." The Psychological Review 2.2: 10524.

James, William. 1904.“Humanism and Truth.” Mind 13.52, pp.457-75.

James, William. 1907. Pragmatism: A new name for some old ways of thinking. New York: Longmans, Green and Co.

James, William. 1909. The Meaning of Truth: A sequel to 'Pragmatism'. New York: Longmans, Green and Co.

McTaggart, John McTaggart Ellis. 1908. “Critical notice of James 1907.” Mind 17.65: 104-9. Pratt, James Bissett. 1909. What is Pragmatism? New York: Macmillan.

Russell, Bertrand. 1908. "Transatlantic Truth.” Albany Review: 393-410.

Schiller, Ferdinand Canning Scott. 1902. “Axioms as Postulates.” In Personal Idealism: Philosophical essays by eight members of the University of Oxford, edited by Henry Stuart, 47-133. London: Macmillan.

Schiller, Ferdinand Canning Scott. 1905. “The Definition of 'Pragmatism' and 'Humanism'.” Mind 14.54: 235-40.

Schiller, Ferdinand Canning Scott. 1907a. Studies in Humanism. London: Macmillan.

Schiller, Ferdinand Canning Scott. 1907b. “Critical Notice of James 1907.” Mind 16.64: 598604.

Schiller, Ferdinand Canning Scott. 1908. "The Tribulations of Truth.” Albany Review 12.11: 624-34.

Schiller, Ferdinand Canning Scott. 1909a. "Humanism and Intuitionism.” Mind 18.69: 1258.

Schiller, Ferdinand Canning Scott. 1909b. “Solipsism.” Mind 18.70: 169-83.

Schiller, Ferdinand Canning Scott. 1909c. "The Rationalistic Conception of Truth." Proceedings of the Aristotelian Society 9: 85-99.

Schiller, Ferdinand Canning Scott. 1910a. "Are Secondary Qualities Independent of Perception?" Proceedings of the Aristotelian Society 10: 218-31.

Schiller, Ferdinand Canning Scott. 1910b. “Critical notice of James 1909.” Mind 19.74: 25863.

Schiller, Ferdinand Canning Scott. 1911. "Error." Proceedings of the Aristotelian Society 11: 144-65.

Schiller, Ferdinand Canning Scott. 1912a. "Critical notice of Vaihinger 1911.” Mind 21.81: 93-104.

Schiller, Ferdinand Canning Scott. 1912b. “The 'Working' of 'Truths'.” Mind 21.84: 532-5.

Schiller, Ferdinand Canning Scott. 1913. "The 'Working' of Truths and their 'Criterion'." Mind 22.88: 532-8.

Skrupskelis, Ignas K., and Elizabeth M. Berkeley, eds. (2002). The Correspondence of William James. Volume 10. 1902 - March 1905. Charlottesville: University of Virginia Press. 
Skrupskelis, Ignas K., and Elizabeth M. Berkeley (2003). The Correspondence of William James. Volume 11. April 1905 - March 1908. Charlottesville: University of Virginia Press.

Skrupskelis, Ignas K., and Elizabeth M. Berkeley (2004). The Correspondence of William James. Volume 12. April 1908 - August 1910. Charlottesville: University of Virginia Press.

Stout, George Fredrick. 1907. "Critical notice of Schiller 1907a." Mind 16.64: 579-88.

Vaihinger, Hans. 1911. Die Philosophie des Als Ob: System der theoretischen, praktischen und religiösen Fiktionen der Menschheit auf Grund eines idealistischen Positivismus, mit einem Anhang über Kant und Nietzsche. Berlin: Reuther und Reichard.

Yolton, John W. 1950. “F. C. S. Schiller's Pragmatism and British Empiricism.” Philosophy and Phenomenological Research 11.1:40-57. 